\title{
Study on Construction of Faculty and Cultivation of Outstanding College and University Teachers
}

\author{
Tao Ying \\ Personnel department, Mudanjiang Normal University, Mudanjiang 157012, P.R China
}

\begin{abstract}
the purpose of this paper is to study how to cultivate a university teacher with noble morality, loyal and dedicated to education, rigorous scholarship, and teach by personal example as well as verbal instruction, then he is able to shoulder the historic mission of" Morality Fostering and Talents Cultivating". We employed inductive and deductive method, and based on the author's work experience of many years in the college personnel department and the research of relevant theories. First of all, we studied some strengthening teacher construction way of improving training mechanism, promoting team building, optimizing the evaluation system and highlighting the humane care. Then, we proposed a scientific strategy for training distinguished teachers, including implementation of the training project of the outstanding teachers and focusing on the construction of teaching successors for quality courses.
\end{abstract}

Keywords: faculty; colleges and universities; outstanding teachers

\section{Introduction}

As a valuable resource for higher education, outstanding teachers have played a role of teaching demonstration, research models and study style role models. Since 2003, China has set the "College and University Distinguished Teacher
Award" as the permanent administrative recognition project of Ministry of Education. Over the seven years, more than 700 teachers has been voted. The purpose of this award is to encourage professors to be involved in teaching practice for enhancing the teaching quality of colleges and universities, and to promote the faculty construction of colleges and universities through awarding those distinguished teachers who have been active in teaching for a long term and have made outstanding contributions. This program fully reflects the party and the country's emphasis on the importance of the quality of higher education and the quality of university teachers, aiming at promoting professors to step up the teaching platform to teach undergraduate students through the recognition of outstanding teachers. Besides, it is also conductive to forming positive atmosphere of learning from the outstanding teachers and striving to be one of them [1]. The election of national university teaching candidates should be based on the recognition results of university-level and provincial-level distinguished teacher awards. Therefore, in order to enhance the quality of teachers and improve the quality of personnel training, government, educational and administrative departments and universities of all levels should adopt effective strategies to strengthen the construction of teaching staff and cultivation of outstanding teachers. 


\section{Methods}

This paper adopts the inductive and deductive method, and based on the author's work experience of many years in the college personnel department and the research of relevant theories, it begins from the analysis of the relationship between the teacher team building and training of teachers, and then studies an effective way of strengthening teacher construction, and finally proposes a scientific strategy for training distinguished teachers.

\section{Approaches to strengthening the faculty construction}

\subsection{Improve training mechanism}

To strengthen the faculty construction, colleges and universities need to improve training mechanism of teachers. First, the university leadership must attach great importance to the work of teacher training. To establish a leading group for the teacher training, integrate the force of the whole school, arrange meticulous organizations, and make overall plans, and then implement from top to bottom and make solid progress, so it will lay a solid foundation for the smooth development of the training and build a good platform for the professional development of teachers. Support and encourage teachers to take refresher training, in particular to supporting the further learning of teaching in emerging discipline or majors short of professional instructors. Second, improve the management mechanism of teacher training. The establishment and improvement of teacher management mechanism is an important part and protection of building teaching team and also a necessary prerequisite to improving the quality and professional level of teachers. The school should deploy a series of comprehensive teacher management system in aspects of recruiting, training, manage- ment and professional development of teachers. Again, set up the mechanism to ensure funding of teacher training to improve the efficiency of the use of funds and ensure the normal and orderly conduct of the training of teachers. Schools should set up special funds for teachers training, specify training funds use, and strengthen training funds audit.

\subsection{Promote team building}

Colleges and universities should promote the faculty construction and play the overall effect based on the status of its own faculty and in close connection with the needs of disciplines building. First, they should prepare for the introduction of human resources planning and actively introduce talents in shortage to meet the needs of professional teachers. Particularly, to introduce academic leaders, young pillar teachers, outstanding talents returning from overseas, as well as excellent graduates of the highly educated, and strive to improve the qualifications, titles and disciplinary structure of teachers. Secondly, to conduct a comprehensive assessment of the teachers in the age structure, the knowledge level, academic standards, and teaching ability to form reasonable echelon, ensuring everyone does his best and every talent is fully used. Finally, actively create a harmonious and progressive humanistic atmosphere, promoting teachers to learn from each other, coordinate, and cooperate in order to combine the overall team goals and individual development goals, and thus improving the overall level of the teachers.

\subsection{Optimize the evaluation system}

Strengthening the faculty construction, colleges and universities need to optimize the teacher evaluation system, and gradually form a multi-evaluation system mainly to develop the potential. First, the evaluation target is based on the devel- 
opment, emphasizing the common development of individual teachers and schools. Secondly, the evaluation content should be open with flexible evaluation methods and dynamic evaluation process. Evaluations are carried out through various forms and ways, so that colleges and universities are able to comprehensively examine the overall quality of teachers from all levels and have more in-depth understanding of the strengths and weaknesses of the faculty as well as concerning about the growth and progress of the teachers. Finally, the assessment of teachers' professional ethics needs to be emphasized. Only having good morality standard and high political attainment, can teachers take on the arduous task of cultivating talents and complete the historic mission of higher education.

\subsection{Highlight the humanistic care}

Strengthening the faculty construction, colleges and universities need to highlight the humanistic care management, inspire and mobilize teachers' initiative and work enthusiasm. First, the university should strive to create an atmosphere conducive to the construction and stability of faculty, a harmonious interpersonal environment for teachers exert their abilities to create, democratic and open academic environment and free and comfortable living environment. Besides, it should try to ensure the work environment and deployment of scientific research and teaching resources as well as necessities for the group of teachers. Secondly, it should be concerned about the teachers' professional development needs and actively build a platform for the growth and progress of teachers and treat existing teachers and introduced talents equally. The spirit of caring, understanding and help should be always persisted throughout the faculty construction, thus increasing teachers' sense of belonging and responsibility to schools.

\section{Cultivating the outstanding teach- ers of colleges and universities}

\subsection{Implementing the project of out- standing teachers cultivation}

"Project of Outstanding Teachers Cultivation" is for special faculty construction. Colleges and universities ought to implement it and take effective measures to cultivate a large number of outstanding teachers with noble morality, deep academic attainments, teaching proficiency which act as the pillar and role model in the teaching process. Meanwhile, young teachers should be inspired to concentrate on the reform of teaching methods and improve their teaching level and quality, thereby encouraging more excellent teachers to become the colonel-level, provincial-level and state-level elite. This kind of proactive, enthusiastic and harmonious atmosphere will lay a solid foundation of talents for the sustained and healthy development of China's colleges and universities.

Project of Outstanding Teachers Cultivation should cover the training objectives, selection and management of training objects, training procedures and measures, assessment management and security mechanism, etc. The key point of training is to enhance the training efforts and adopt the strategy of "Sending teachers out for training and introducing teachers outside schools". Encourage the teachers to carry out the overseas studying, the domestic visiting scholar or short-term training. At the same time, tutor team composed by well-known professors, experts, scholars should be equipped for these training objects to be responsible for the recurring and systematic guiding. Set up the special funds of teacher training and make the best use of it, thereby guaranteeing the training quality and effectiveness. What's more, it is necessary to focus on the management and evaluation of training objects, thus 
avoiding the cultivation to become a mere formality.

\subsection{Focus on the faculty echelon building of high-quality course}

The reason why a course is named as the "high-quality course" lies in that teachers responsible for it are working on the teaching research and practice, so it is the hallmark of growth and development as well as the wisdom crystallization of teachers. In the evaluation system of national high-quality course, the Ministry of Education regards the faculty construction as the primary indicator and stresses that the construction of high-quality courses should be associated with highlevel faculty. In addition, it is clearly depicted that high-quality course should be taken charge by the professors with advanced academic attainments and rich teaching experience; by the high-quality course construction, a large number of outstanding faculty will be cultivated and trained, which will gradually form a team of teaching staff with reasonable structure, stable personnel, high teaching level as well as good teaching effect. The primary task of the high-quality course is to create high-level faculty by such a good platform of teaching quality and teaching reform. Therefore, colleges and universities can take advantage of this opportunity---the high-quality course and combine the echelon construction of faculty and outstanding teacher cultivation to gather the teaching and academic team that is harmonious, cooperative, complementary and interactive. Therefore, larger number of elite will participate in it, which is conducive to the effective operation of introduction and cultivation of highquality talents.

\section{Discussion}

Faculty is one of the most important factors influencing the quality of talents training in colleges and universities, and it is also an essential embodiment of their core competitive power. In Hu Jintao's report at 18th Party Congress, the "Morality Fostering and Talents Cultivating" is regarded as the fundamental task of education. Therefore, in the face of the expectation and demands of the Party and the nation, colleges and universities should make great efforts to build a faculty with high-level teaching staff which can satisfy the teaching demands. These teachers play an exemplary role in teaching process, which is conductive to improve the higher education comprehensively and achieve the training for highlevel talents.

\section{References}

[1] Zhang Yizhong, Song Yanting. Outstanding Teachers in Colleges and Universities and Their Formation Mechanism[J]. Journal of Jiangxi Normal University ( Philosophy and Social Sciences Edition ), 2011 ( 4): 39.

[2] Wang Qingsong. On the Connotation and Cultivation of College Teachers [J]. Journal of Guangxi Teachers College (Philosophy and Social Sciences Edition ), 2002 ( 10): 48.

[3] Feng Ying. On the Cultivation of Outstanding Teachers in Higher Vocational Colleges and Teacher Team Construction [J]. China Adult Education, 2010 (18): 33. 